\title{
EFFECT OF THERMO-MECHANICAL TREATMENT ON PROPERTIES OF PARICA PLYWOODS (Schizolobium amazonicum Huber ex Ducke) ${ }^{1}$
}

\author{
Mírian de Almeida Costa ${ }^{2 *}$ and Cláudio Henrique Soares Del Menezzi ${ }^{3}$
}

\footnotetext{
${ }^{1}$ Received on 03.02.2015 accepted for publication on 27.10.2016.

${ }^{2}$ Universidade de Brasília, Doutorado em Ciências Florestais, Brasília, DF - Brasil. E-mail: <almeida.mira@gmail.com>.

${ }^{3}$ Universidade de Brasília, Faculdade de Tecnologia, Departamento de Engenharia Florestal, Brasília, DF - Brasil. E-mail: <cmenezzi@unb.br>.

*Corresponding author.
}

\begin{abstract}
Thermo-mechanical treatment is a technique for wood modification in which samples are densified by means of heat and mechanical compression, applied perpendicularly to fibers, which under different combinations of time, temperature, and pressure increases wood density and thus improve some of its properties. This study aimed to treat thermo-mechanically parica plywood and observe the effects on its physical and mechanical properties. Specimens were submitted to two treatments, 120 and $150{ }^{\circ} \mathrm{C}$, remaining under pressure for seven minutes and, subsequently, under zero pressure for 15 minutes. Results showed a significant increase in specific mass from $0.48 \mathrm{~g} \mathrm{~cm}^{-3}$ to an average of $0.56 \mathrm{~g} \mathrm{~cm}^{-3}$, and a compression ratio of about $31.7 \%$ on average. Physical properties also varied significantly and results showed that treated samples swelled and absorbed more water than those untreated, leading to a greater thickness non-return rate. This indicates the proposed thermal treatments did not release the internal compressive stress generated during panel pressing, not improving its dimensional stability as a result. On the other hand, mechanical properties were positively affected, leading to an increase of $27.5 \%$ and $51.8 \%$ in modulus of rupture after treatments at 120 and $150{ }^{\circ} \mathrm{C}$, respectively. Modulus of elasticity and glue-line shear strength did not vary statistically and Janka hardness was $29.7 \%$ higher after treatment at $150^{\circ} \mathrm{C}$.
\end{abstract}

Keywords: Thermo modification; Wood panels; Densification

\section{EFEITO DO TRATAMENTO TERMO-MECÂNICO SOBRE AS PROPRIEDADES DE COMPENSADOS DE PARICÁ (Schizolobium amazonicum Huber ex Ducke)}

\begin{abstract}
RESUMO - O tratamento termomecânico é uma metodologia para modificação da madeira, onde as amostras são densificadas por meio do calor e da compressão mecânica aplicada perpendicularmente às fibras, que submetidas a diversas combinações de tempo, temperatura e pressão aumentam a densidade da madeira e assim melhoram algumas de suas propriedades. Opresente trabalho teve como objetivo tratar termomecanicamente compensados de paricá e observar os efeitos nas suas propriedades fisicas e mecânicas. Os corpos-de-prova foram submetidos a dois tratamentos: a $120^{\circ} \mathrm{Ce} \mathrm{a} 150^{\circ} \mathrm{C}$, mantidos sob pressão por sete minutos e, posteriormente, sob pressão zero, por quinze minutos. Os resultados mostraram que houve aumento significativo da massa específica de $0,48 \mathrm{~g} / \mathrm{cm}^{3}$ para, em média, $0,56 \mathrm{~g} / \mathrm{cm}^{3}$, e a taxa de compressão foi de $31,7 \%$ em média. As propriedades fisicas também variaram significativamente, e os resultados mostraram que as amostras tratadas incharam e absorveram mais água que as testemunhas, levando a uma maior TNRE (taxa de não-retorno em espessura). Isto indica que os tratamentos térmicos propostos não liberaram as tensões internas de compressão geradas durante a prensagem do painel, não melhorando sua estabilidade dimensional. As propriedades mecânicas, por sua vez, foram afetadas positivamente, levando a um aumento de 27,5\% e 51,8\% do MOR após os tratamentos a $120^{\circ} \mathrm{C}$ e a $150^{\circ} \mathrm{C}$, respectivamente. $\mathrm{O} M O E$ e o cisalhamento na linha de cola não variaram estatisticamente e, a dureza Janka, ficou $29,7 \%$ maior após o tratamento a $150^{\circ} \mathrm{C}$.
\end{abstract}

Palavras-chave: Modificação térmica; Painéis de madeira; Densificação. 


\section{INTRODUCTION}

Thermo-mechanical treatment is a method for modifying wood, which is densified by means of heat and mechanical compression applied perpendicular to fibers, which, under different combinations of time, temperature, and pressure, increase wood density and thus improve some of its properties. Thermo-mechanical treatment is also a way to convert soft and porous woods into denser woods that can be used in situations where greater resistance is required. Likewise, this treatment can be used on wood laminates used for manufacturing plywood and LVL (Laminated Veneer Lumber). A previous densification of laminates can reduce the total pressing time of a panel and amount of adhesive used, in addition to improving mechanical properties (Kurowska et al., 2010; Arruda et al., 2011; Arruda, 2012; Fang et al., 2012).

Parica wood presents a medium density, which is a significant technical advantage in manufacturing plywood laminates for structural purposes, which requires greater mechanical resistance. Recent studies show that $30 \%$ of laminates produced with this species are used as a cover (plywood outer shell) and the remaining as a core, i.e. the inner part (Rossi et al., 2003).

Thermo-mechanical treatment can also be applied during or after panel consolidation, making it less hygroscopic and resistant to biological attack (Currier, 1962; Haygreen and Daniels, 1969; Heger et al., 2004; Unsal et al., 2010; Mendes et al., 2013). Regarding thermomechanical treatments in the post-production of plywood, the literature is still scarce.

This study aimed to determine and compare values of the main physicomechanical properties of parica plywood densified by thermo-mechanical treatment in order to quantify its possible gains in resistance, rigidity, and dimensional stability in relation to an untreated plywood.

This study is justified by the fact that thermomechanical treatments can help improve final product quality, reducing dimensional instability of wood and products such as panels because they reduce moisture content and liquid absorption, in addition to making them more mechanically resistant. Furthermore, the use of this treatment in parica plywood panels can encourage research with other tropical species less used, relieving the pressure on those most sought-after ones.

\section{MATERIALAND METHODS}

Water-resistant plywood panels (WRP) with 20 $\mathrm{mm}$ thickness, bonded with phenolic resin, were purchased in Brasília - DF, Brazil. In order to determine the temperature, pressure, and time of treatments, a pre-test was performed (Costa and Del Menezzi, 2014). After analyzing the obtained results, two treatments were selected, as can be observed in Table 1 .

The pressure in press gauge for the densification process was calculated according to Equation 1, using $50 \%$ of the perpendicular compression resistance of parica wood, which is equal to 5.88 MPa (IBAMA, 2001).

$$
\mathrm{P}_{\mathrm{G}}=\frac{\mathrm{P}_{\mathrm{s}}-\mathrm{A}_{\mathrm{p}}}{551.55}
$$

Where:

$\mathrm{P}_{\mathrm{G}}=$ gauge pressure, in ${\mathrm{kgf} \mathrm{cm}^{-2}}$;

$\mathrm{P}_{\mathrm{s}}=$ specific pressure of parica, in $\mathrm{kgf} \mathrm{cm}^{-2}$;

$\mathrm{A}_{\mathrm{p}}=$ area of panels, in $\mathrm{cm}^{2}$.

After press closure, records of pressure corrections were taken frequently, which was made to keep it constant. These corrections occurred because the glass transition temperature has been reached, making wood malleable, and leading to a required pressure reduction to keep it compressed. When treatment temperature was reached, material was maintained under pressure during seven minutes and subsequently under zero pressure during 15 minutes.

This is a crucial stage in which the compressive stress relaxation occurs, which will reflect on dimensional stability of the material, thus characterizing the posttreatment. Subsequently, panels were removed from the press for cooling and then taken to climatization to proceed with the measurements.

Table 1 - Thermo-mechanical treatments applied to parica plywood.

Tabela 1 - Tratamentos termomecânicos aplicados no compensado de paricá.

\begin{tabular}{ccccc}
\hline Treatment & Temperature & Pressure & Time under pressure (min.) & Time after zeroed pressure (min.) \\
\hline 1 & $120^{\circ} \mathrm{C}$ & $50 \%$ & 7 & 15 \\
\hline
\end{tabular}


The mechanical properties were assessed according to the standard ASTM D1037 (1999), being static bending in the direction perpendicular to fibers, obtaining the modulus of elasticity $\left(E_{M}\right)$ and modulus of rupture $\left(f_{M}\right)$, and Janka hardness $\left(\mathrm{f}_{\mathrm{H}}\right)$. The glue-line shear strength $\left(\mathrm{f}_{\mathrm{gv}, 0}\right)$ was assessed according to the European standard EN 314-1 (2004).

Static bending tests were performed with 10 samples from each treatment and controls, with dimensions of $45 \times 260 \mathrm{~mm}$ and thickness varying according to the treatment. The span used varied according to the final mean thickness of each treatment, characterizing mainly plywood hardness and resistance, also serving to assess whether the densification resulted in significant gains in these properties. From these samples, others were taken in order to perform Janka hardness. These tests were carried out in a universal testing machine (EMIC), with a maximum load capacity of $300 \mathrm{kN}$.

In order to perform Janka hardness test, specimens of $45 \times 50 \mathrm{~mm}$ were glued two by two to meet the standard minimum thickness requirement. Thus, 10 replications were used for each treatment.

The glue-line shear strength $\left(f_{\mathrm{gv}, 0}\right)$ was performed to assess the influence of treatment on plywood gluing quality using the same universal testing machine and 10 specimens of $25 \times 90 \mathrm{~mm}$ per treatment.

Water absorption and volumetric and thickness swelling tests, obtained according to the standard ASTM D 1037 (ASTM, 1999), as well as equilibrium moisture content (EMC), were performed to obtain the hygroscopic behavior of panels and observe the densification treatment contribution to the dimensional stability of the material. These tests were performed by using 10 samples of $45 \times 45 \mathrm{~mm}$ from each treatment, being submerged in ambient temperature water during a 24-hour period, within which, every 2 and 24 hours, mass and dimensions were measured with a precision balance and dial indicator.
Mass loss (ML, \%) and compression ratio (CR, \%) were also measured in the 10 treated samples of $45 \times 45 \mathrm{~mm}$ from each treatment. ML is the pre-treatment mass to post-treatment mass ratio and refers to the total sample mass loss, which includes water and extractives loss as well as wood polymers degradation. If ML is lower than the initial EMC, it means that there was no effective mass loss, i.e. ML was related only to water loss. CR represents the degree of material densification, relating the final to the initial thickness of a sample. The higher the $\mathrm{CR}$ is, the greater the degree of material densification. ML and CR were measured after climatization.

After swelling and absorption tests, specimens were dried in an oven until constant weight and subsequently the thickness non-return rate (TNRR) was measured. This measure represents the swelling caused by the release of compressive stress during plywood pressing. These data, together with thickness swelling data ( 2 and $24 \mathrm{~h}$ ) and water absorption ( 2 and $24 \mathrm{~h}$ ), were used to determine thermal treatment efficiency in improving dimensional stability. EMC was obtained from the same specimens after measuring TNRR, according to the standard ASTM D 4442 (ASTM, 2007).

\section{RESULTS}

Table 2 shows the specific mass (SM) and compression ratio of plywood. Specific mass varied significantly, with averages of 0.447 and $0.560 \mathrm{~g} \mathrm{~cm}^{\prime \prime}$ for untreated and treated panels, respectively. A high compression ratio was observed resulting in increased density. CR also varied significantly, which means an average reduction in material thickness of $31.69 \%$.

Table 3 shows the average of physical properties of treated and untreated panels. Treated panels presented lower values for all properties when compared to those untreated, except for the equilibrium moisture content. This is due to a greater water absorption and thickness swelling, which reflected in an increased TNRR.

Table 2 - Specific mass (SM) and compression ratio (CR) of treated and untreated samples of parica plywood. Tabela 2-Massa específica (ME) e taxa de compressão (TC) das testemunhas e das amostras tratadas de compensado de paricá.

\begin{tabular}{ccc}
\hline Treatment & $\mathrm{SM}\left(\mathrm{g} \mathrm{cm}^{\mathfrak{B}}\right)$ & $\mathrm{CR}(\%)$ \\
\hline Control & 0.447 & - \\
$\mathrm{T} 1\left(120^{\circ} \mathrm{C}, 77^{\prime}, 15^{\prime}\right)$ & 0.594 & 28.51 \\
T2 $\left(150^{\circ} \mathrm{C}, 7^{\prime}, 30^{\prime}\right)$ & 0.639 & 34.88 \\
Average of treatments & 0.560 & 31.69 \\
\hline
\end{tabular}


Table 3 - Dimensional stability properties of parica plywood panels.

Tabela 3 - Propriedades de estabilidade dimensional dos painéis compensados de paricá.

\begin{tabular}{lccccccc}
\hline Treatment & \multicolumn{7}{c}{ Property $(\%)$} \\
\hline & TS2h & TS24h & WA2h & WA24h & EMC & ML & TNRR \\
Control & $2.19^{\mathrm{a}}$ & $3.17^{\mathrm{a}}$ & $30.29^{\mathrm{a}}$ & $59.58^{\mathrm{a}}$ & $11.02^{\mathrm{a}}$ & - & $2.41^{\mathrm{a}}$ \\
T1 $\left(120^{\circ} \mathrm{C}, 7^{\prime}, 15^{\prime}\right)$ & $16.62^{\mathrm{b}}$ & $22.85^{\mathrm{b}}$ & $38.21^{\mathrm{b}}$ & $67.67^{\mathrm{b}}$ & $10.43^{\mathrm{b}}$ & $6.63^{\mathrm{a}}$ & $8.84^{\mathrm{b}}$ \\
T2 $\left(150^{\circ} \mathrm{C}, 7^{\prime}, 15^{\prime}\right)$ & $20.32^{\mathrm{b}}$ & $27.50^{\mathrm{b}}$ & $38.54^{\mathrm{b}}$ & $70.52^{\mathrm{b}}$ & $9.61^{\mathrm{c}}$ & $9.99^{\mathrm{b}}$ & $10.58^{\mathrm{c}}$ \\
Average of treatments & 18.47 & 25.17 & 38.37 & 69.10 & 10.02 & 8.31 & 9.71 \\
\hline
\end{tabular}

Equal letters do not differ statistically from each other. TS2h - thickness swelling after 2-hour immersion; TS24h - thickness swelling after 24-hour immersion; WA2h - water absorption after 2-hour immersion; WA24h - water absorption after 24-hour immersion; EMC - equilibrium moisture content; ML - mass loss; TNRR - thickness non-return rate.

Equilibrium moisture content presented good responses to thermal treatments, as can be seen in Table 3. It differed statistically between treatments since it presented values from $11.02 \%$ to $10.43 \%$ after Treatment 1 and to $9.61 \%$ after Treatment 2 . In its turn, mass loss, which is related to wood degradation due to temperature increase and duration of panel treatment, presented average values of $6.63 \%$ after Treatment 1 and $9.99 \%$ after Treatment 2 .

Moreover, TNRR values of treated plywood were significantly higher than those untreated (Table 3 ), which presented a value of $2.41 \%$. Although with a tendency to increase as temperature increases, the values of analyzed properties did not show statistical differences, except for TNRR, which presented a value $17.5 \%$ higher.

Table 4 shows the average of mechanical properties of treated and untreated panels. No one of the treated panels showed a reduction in mechanical properties when compared to those untreated ones.

Modulus of rupture $\left(\mathrm{f}_{\mathrm{M}}\right)$ presented values from 26.50 $\mathrm{MPa}$ (control) to $33.80 \mathrm{MPa}\left(\right.$ at $120^{\circ} \mathrm{C}$ ) and 40.23 $\mathrm{MPa}\left(\right.$ at $\left.150^{\circ} \mathrm{C}\right)$, which represents an increase of 27.5 and $51.8 \%$, respectively. On the other hand, modulus of elasticity $\left(\mathrm{E}_{\mathrm{M}}\right)$ was not influenced by treatments, remaining statistically equal to control. However, a clear tendency for this effect was observed, i.e., the higher the temperature is, the greater the increment in material rigidity.

Thermo-mechanical treatment at $120^{\circ} \mathrm{C}$ had no effect on plywood hardness, which reached 1954.1 N and remained statistically equal to control (1639.1 N). However, Tukey's test showed that the treatment at $150^{\circ} \mathrm{C}$ was significantly higher in hardness than control, reaching a value of $2126.1 \mathrm{~N}$, which is $29.7 \%$ higher.

As occurred for modulus of elasticity, the glueline shear strength of plywood was not affected after treatment. In control, $\mathrm{f}_{\mathrm{gv}, 0}$ presented a value of 0.79 $\mathrm{MPa}$ and increased to $1.35 \mathrm{MPa}$ at $120^{\circ} \mathrm{C}$ and to 1.05 MPa at $150^{\circ} \mathrm{C}$.

\section{DISCUSSION}

The average CR of $31.69 \%$ reached by using a pressure of $14.7 \mathrm{~N} \mathrm{~mm}^{-2}$ was similar to that obtained by Bekhta and Marutzky (2007), who observed a CR of $33 \%$ by using a pressure of $15 \mathrm{~N} \mathrm{~mm}^{-2}$ in beech laminates (Fagus sp.) before using them for plywood manufacturing. Arruda (2012) produced plywood with thermally treated laminates of amescla wood and obtained a CR ranging from $10.54 \%$ (at $140^{\circ} \mathrm{C}$ ) to $15.51 \%$ (at $\left.180^{\circ} \mathrm{C}\right)$.

Bekhta et al. (2012) observed a clear relationship between compression ratio and treatment parameters, such as temperature, pressure, and time. According

Table 4 - Mechanical property values of parica plywood panels.

Tabela 4 - Valores das propriedades mecânicas dos painéis compensados de paricá.

\begin{tabular}{lcccr}
\hline Treatment & \multicolumn{3}{c}{ Property (MPa) } \\
\cline { 2 - 5 } & $\mathrm{f}_{\mathrm{M}}$ & $\mathrm{E}_{\mathrm{M}}$ & $\mathrm{f}_{\mathrm{H}}$ & $\mathrm{f}_{\mathrm{gv}, 0}$ \\
\hline Control & $26.50^{\mathrm{a}}$ & $3161.4^{\mathrm{a}}$ & $1639.2^{\mathrm{a}}$ & $0.79^{\mathrm{a}}$ \\
$\mathrm{T} 1\left(120^{\circ} \mathrm{C}, 7^{\mathrm{a}}, 15^{\prime}\right)$ & $33.80^{\mathrm{b}}$ & $4443.4^{\mathrm{a}}$ & $1954.1^{\mathrm{b}}$ & $1.35^{\mathrm{a}}$ \\
$\mathrm{T} 2\left(150^{\circ} \mathrm{C}, 7^{\prime}, 15^{\prime}\right)$ & $40.23^{\mathrm{b}}$ & $5066.7^{\mathrm{a}}$ & $2126.1^{\mathrm{b}}$ & $1.05^{\mathrm{a}}$ \\
\hline
\end{tabular}

Equal letters do not differ statistically from each other. $\mathrm{f}_{\mathrm{M}}-$ modulus of rupture; $\mathrm{E}_{\mathrm{M}}-$ modulus of elasticity; $\mathrm{f}_{\mathrm{H}}-$ Janka hardness; $\mathrm{f}_{\mathrm{gv}, 0}-$ glue-line shear strength.

Revista Árvore. 2017;41(1):e410115 
to these authors, the compression ratio is more sensitive to temperature increase than pressure or time. Inoue et al . (1993) cited the relationship between compression ratio and basic density and found an increase in density from 0.36 to $0.50 \mathrm{~g} \mathrm{~cm}^{-3}$ with a compression degree of $30 \%$. At a compression ratio of $60 \%$, density increased to $0.9 \mathrm{~g} \mathrm{~cm}^{-3}$, which represents more than twice the initial density. In this study, which presented a CR slightly higher than $30 \%$, density increased from 0.44 to $0.59 \mathrm{~g} \mathrm{~cm}^{-3}$ after Treatment 1 and to $0.63 \mathrm{~g} \mathrm{~cm}^{-3}$ after Treatment 2, representing an increase of 33 and $42 \%$, respectively.

Kutnar and Sernek (2007) explained that an increase in density after a densification treatment will depend on several factors such as wood type, product thickness, how the wood is in the product (shape and particle size) and the applied treatments (pressure and/or heat). In general, an increase in density occurs at a rate of 25 to $500 \%$, with a preferred rate of up to $200 \%$.

The values obtained for physical properties (water absorption and thickness swelling after 2- and 24-hour immersion and TNRR) indicated that the proposed thermal treatments changed the relationships between water and wood, but in an unexpected way, since it is known that reducing wood's ability to absorb water by thermo-mechanical treatments, for example, an improvement in dimensional stability occurs. These values were higher in treated samples than in those untreated, which means the proposed thermal treatments did not release the internal compressive stresses generated during panel pressing. Similar results were also reported by Arruda et al. (2003), who treated thermally amescla laminates at 140 and $180^{\circ} \mathrm{C}$ prior to plywood panel manufacturing; and by Arruda et al. (2011), who treated parica laminates at $150{ }^{\circ} \mathrm{C}$ and did not observe any tendency to reduce swelling with increasing treatment time. Del Menezzi (2004) also observed some negative results regarding swelling and TNRR by treating thermally OSB panels. An increase in temperature or treatment time could cause a greater reduction in water absorption. For an improvement in dimensional stability of panels, a significant reduction in thickness swelling and water absorption would be necessary.

Stresses are released according to the viscoelastic polymer nature composing the wood. Variations in its physical state occur depending on the temperature at which the polymer is. The temperature that divides the states is known as viscoelastic transition temperature (Tg), which varies with moisture. For lignin, the equilibrium moisture is reached at approximately $170^{\circ} \mathrm{C}$ (HSU et al., 1989). Thus, when lignin is below this temperature, it behaves as a rigid solid (vitreous). However, when it is at a temperature above $170{ }^{\circ} \mathrm{C}$, it behaves as a viscous polymer, losing its rigidity. Under this condition, which should have been provided by thermal treatment, the compressive stresses are released.

Unsal et al. (2011) observed a greater thickness swelling in samples of Eucalyptus camaldulensis treated at 130 and $150^{\circ} \mathrm{C}$ and several pressures when compared to controls. The authors attributed this effect to springback and cited the study of Unsal et al. (2009), who studied pinewood and observed that the higher the pressure used in thermal treatment is, the higher the values of water absorption and swelling. In addition, these authors stated that the springback phenomenon is much more related to pressure level than to temperature degree, which is mostly related to permanent deformation of the material.

According to Del Menezzi (2004), EMC relates a number of water molecules adsorbed in sites of hydroxyl groups of the cell wall. Therefore, thermal treatments reduced these sites in such a magnitude implying in EMC reduction. Moreover, thermal treatment alters the structure of wood polymers, making them less hygroscopic or even transforming them chemically. Stamm et al. (1946) demonstrated that to reach a $40 \%$ efficiency in dimensional stability, the mass loss should be $8 \%$, close to that reached by the treatments tested here. With increasing temperature and treatment duration, mass loss increases (Esteves et al., 2008). These authors observed for samples of Pinus pinaster a maximum reduction in EMC when mass loss reached 4\%. Furthermore, at a temperature of $170{ }^{\circ} \mathrm{C}$ for 5 hours, mass loss is less than $1 \%$; however, by increasing temperature to $200{ }^{\circ} \mathrm{C}$ and keeping the time constant, mass loss increases to $5 \%$.

Frequently, effective mass loss (EML), which is the difference between ML and EMC values before treatment in percentage, is calculated to finding out the effectiveness of a treatment. If EML is positive, i.e. if ML is higher than EMC, the amount of heat applied was adequate to evaporate the water and degrade some other wood components. For any of the treatments, ML was higher than EMC before treatments (control), indicating that there was not enough heat to eliminate 
the water from the samples. EML was calculated by Arruda et al. (2011), who treated thermally parica laminates at $150{ }^{\circ} \mathrm{C}$ for 5,10 , and 15 minutes and, in most of the samples, this value was negative. In samples which EML was positive, treatment was the longest, being applied for 15 minutes.

A material with high TNRR has greater swelling and expansion in thickness. Since TNRR represents the swelling caused by stress release, treated plywood accumulated the preexisting stress since panel manufacturing and those introduced with treatment application, leading to higher treated TNRE.

Moreover, in bonded materials, the release of compressive stresses causes loss of bonding quality. Thus, gluing quality is important to keep the panel bonded and limit stress release (Mohebby et al., 2009).

Increases in modulus of elasticity and rupture have been widely reported in the literature, especially increasing material density(kamke, 2006; sundqvist et al., 2006; Gáborík et al., 2011). Hillis (1984) and Yildiz et al. (2006) observed that by using only thermal treatments, without compression influence, modulus of rupture is usually more affected than the modulus of elasticity. However, this was the effect reached in this study, even using pressure along with heat. Thus, Treatment 2 was advantageous for plywood static flexion since it made the material more resistant to rupture load, without reducing the elastic deformation resistance. Even though the decrease in $\mathrm{E}_{\mathrm{M}}$ is common in thermal treatments due to thermal degradation of polymers and wood mass loss, this property was not significantly affected by treatment. The densification caused by mechanical compression, which was favored by temperature, contributed to increase plywood rigidity because empty spaces were reduced, increasing the proportion of mass in relation to volume.

Increasing hardness can be attributed to an increase in surface density of panels caused by heat treatment. Other authors have also obtained similar results, such as Arruda (2012), who observed hardness values from $17 \mathrm{~N} \mathrm{~mm}^{-2}$, for untreated amescla wood, to $45 \mathrm{~N} \mathrm{~mm}^{-2}$, for those treated at $200{ }^{\circ} \mathrm{C}$. Dogu et al. (2010) treated pine samples at 120 and $150{ }^{\circ} \mathrm{C}$ for 60 minutes and observed an increase in Janka hardness and density. These authors stated that wood deformation is due to temperature increase rather than an increase in its compression.
Glue-line shear strength remained statistically equal to controls, indicating that thermal treatments did not compromise bonding quality, as observed by Larissa et al. (2011). Shear strength of plywood manufactured from thermally treated parica laminates decreased $16.70 \%$ in the treatment at $150{ }^{\circ} \mathrm{C}$ for 15 minutes when compared to control. Grzeskiewiczet al. (2009) observed a decrease of up to $84.21 \%$ for glue-line shear strength in the most severe treatment $\left(220^{\circ} \mathrm{C}\right.$ for two hours $)$.

\section{CONCLUSION}

The thermo-mechanical treatment made plywood denser and with lower equilibrium moisture content.

Due to the release of compressive stresses, thickness swelling, water absorption and thickness non-return rate presented higher values for treated plywood, which made them less dimensionally stable. However, thermomechanical treatment improved the modulus of rupture and hardness, not affecting negatively the other mechanical properties tested.

For further studies, it is recommended an investigation of thermo-mechanical treatments concomitantly to plywood pressing at manufacturing and consolidation. In addition, economic analyses should be performed to verify the viability of this treatment.

\section{ACKNOWLEDGEMENTS}

The authors would like to thank the University of Brasília and the Laboratory of Forest Products (LPF/ SFB) for technical support and CAPES for financial support.

\section{REFERENCES}

Arruda LM, Gonçalez, JC, Del Menezzi CHS, Melo RR. Estudo preliminar das propriedades de compensados produzidos com lâminas de paricá (Schizolobium amazonicum Huber ex Ducke) modificadas termomecanicamente. Ciência da Madeira. 2011;2(1):29-42.

Arruda LM. Modificação termomecânica da madeira de amescla (Trattinnickia burseraefolia (Mart.) Willd.): efeito sobre as propriedades de lâminas e compensados [dissertação]. Brasília: Universidade de Brasília; 2012.

American Society For Testing And Materials ASTM. ASTM D 1037. Standard test methods of 
evaluating properties of wood-based fiber and particle panel materials. Annual book of ASTM standards, v. 15.03. West Conshohocken: 1999.

American Society For Testing And Materials ASTM. ASTM D 4442. Standard test methods for direct moisture content measurement of wood and wood-base materials. Annual Book of ASTM Standards, v. 04.09. West Conshohocken: 2001.

Bekhta P, Marutzky R. Reduction of glue consumption in the plywood production by using previously compressed veneer. European Journal of Wood and Wood Products. 2007; 65(1):87-8.

Bekhta P, Niemz P, Sedliacik J. Effect of prepressing of veneer on the glueability and properties of veneer-based products. European Journal of Wood and Wood Products. 2012;70(1-3):99-106.

Currier RA. Compression of Douglas fir plywood in various hot-pressing cycles. Corvallis: Oregon State University, Forest Research Laboratory; 1962. (Information circular, 17).

Costa MAC, Del Menezzi CHS. Thermomechanical modification effects on Parica (Schizolobium amazonicum) plywood properties. In: Anais of the 7 th. European Conference on Wood Modification. Lisboa: 2014; 27-8.

Del Menezzi CHS. Estabilização dimensional por meio do tratamento térmico e seus efeitos sobre as propriedades de painéis de partículas orientadas (OSB) [dissertação]. Curitiba: Universidade Federal do Paraná; 2004.

Dogu D, Tirak K, Candan Z, Unsal O. Anatomical investigation of thermally compressed wood panels..BioResources. 2010;5:2640-63.

Esteves B, Domingos I, Pereira H. Melhoramento Tecnológico por Modificação Térmica de Madeiras Portuguesas. In: Anais do Congresso Florestal Nacional. Lisboa: 2005;364p.

Fang CH, Cloutier A, Blanchet P, Koubaa A. Densification of wood veneers combined with oilheat treatment. Part II: hygroscopicity and mechanical properties. BioResources. 2012;7:925-35.
Gáborík J, Joščák P, Kulík J, Grznárik T. Properties of compressed laminated beech wood by bending stress. Forestry and Wood Technology. 2011(74):63-8.

Grzeskiewicz M, Borysiuk P, Jaskólowski W. Physical and mechanical properties and burning behavior of beech plywood made of thermally modified veneers. In: Proceedings of the 13rd. International Panel Products Symposium. Nantes: IPPS; 2009. p.1-36.

Haygreen JG, Daniels DH. The simultaneous drying and densification of sapwood. Wood and Fiber Science. 1969;1:1-16.

Heger F, Groux M, Girardet F, Welzbacher C, Rapp AO. Mechanical and Durability Performance of THM-Densified Wood. In: Proceedings of the Environmental Optimization of Wood Protection. Lisboa: 2004.

Hillis WE. High temperature and chemical effects on wood stability Part 1: General considerations. Wood Science Technology. 1984;18:281-93.

Hsu WE, Schwald W, Shields JA. Chemical and physical changes required for producing dimensionally stable wood-based composite. Part 2: heat post-treatment. Wood Science Technology. 1989;23:281-8.

Instituto Brasileiro do Meio Ambiente e dos Recursos Naturais Renováveis- IBAMA. Banco de dados de madeiras brasileiras [internet]. 2001. [acessado em: set. 2013]. Disponível em: http:/ /www.ibama.gov.br/lpf/madeira.

Inoue M, Norimoto M, Tanahashi M, Rowell RM. Steam or heat fixation of compressed wood. Wood and Fiber Science. 1993;25:224-35.

Kamke FA. VTC Wood - the next generation wood product. Corvallis: Oregon State University; 2006.

Kurowska A, Borysiuk P, Mamiński M, Zbieć M . Veneer densification as a tool for shortening of plywood pressing time. Drvna Industrija. 2010;61(3):193-6.

Kutnar A, Sernek M. Densification of wood. Zbornikgozdarstva in Lesarstva. 2007;82:53-62.

Mendes RF, Bortoletto Júnior G, Júnior GB, Almeida NF, Surdi PG, Barbeiro IN. Effect of 
thermal treatment on properties of OSB. Wood Science and Technology. 2013;47:243-56.

Mohebby B, Gorbani-Kokandeh M, Soltani M. Springback in Acetylated Wood Based Composites. Construction and Building Materials. 2009; 23(9):3103-6.

Rossi LMB, Souza CR, Azevedo CP, Vieira AH. Aspectos silviculturais e socioeconômicos de uma espécie de uso múltiplo: o caso de Schizolobium amazonicum Huber ex. Ducke [internet]. 2003. [acessado em: out. 2014]. Disponível em: http:// www.abeas.com.br/anuncios/8cong/Artigos/ Silvicultura/8CFNP_D01.doc

Stamm AJ, Burr HK, Kline A. Staybwood. HeatStabilized wood. Industrial and Engineering Chemistry. 1946;38(6):630-4.

Sundqvist B, Karlsson O, Westermark U. Determination of formic-acid and acetic acid concentrations formed during hydrothermal treatment of birch wood and its relation to colour, strength and hardness. Wood Science and Technology. 2006;40:549-61.

Unsal O, Kartal SN, Candan Z, Arango RA, Clausen CA, Green F. Decay and termite resistance, water absorption and swelling of thermally compressed wood panels. International Biodeterioration \& Biodegradation. 2009;63(5):548-52.

Unsal O, Candan Z, Buyuksari U, Korkut S, Babiak M. Effects of thermal modification on surface characteristics of OSB panels. Wood Research. 2010;55(4):51-8.

Unsal O, Candan Z, Buyuksari U, Korkut S, Chang YS, Yeo H. Effect of thermal compression treatment on the surface hardness, vertical density profile and thickness swelling of eucalyptus wood boards by hot-pressing. Mokchae Konghak.

2011;39(2):148-55. 